collects its own drinking water from a comparatively pure source, and then adopts the selfish policy of permitting its refuse matter to enter the stream below its own intake, with too little regard for the needs of its neighbour lower down the course of the same river. Perhaps it is hardly to be expected that, of its own initiative, a sanitary authority will face a great deal of extra trouble and expense (beyond what is necessary for its own purposes) in conserving the quality and quantity of water when the entire benefit is to be reaped by other authorities; and this is one of the reasons why a general policy should be adopted and enforced by a central authority.

Although certain river conservancy boards exist and have done good work, and several county councils have done much to reduce the contamination of streams, these bodies are unable to do all that is necessary. The Rivers Pollution Prevention Act of 1876 was not framed so as to render the assistance which such an Act could be made capable of, and most of our larger rivers course through more than one county or between the existing purely arbitrary boundary of counties. The rivers and watersheds of the country are, moreover, generally too extensive to be embraced by any existing sanitary authority.

The case in favour of putting the whole of the watershed areas under one controlling authority is therefore a very strong one. The matter, both in its magnitude and importance, is clearly a national one, and a central authority for the whole country is what is needed. The duty of such an authority would be to maintain a sufficient sanitary supervision and control over authorities whose districts form important catchment areas for our water supplies, with the view of maintaining the purity and volume of the waters at standards sufficient to meet the domestic and trade demands of the country as a whole. Such an authority would also arbitrate and advise upon points in dispute between sanitary authorities, or between sanitary authorities and local industries--in so far as these matters relate to the contamination of water: and the heavy expenditure now entailed by costly and often ill-advised litigation, frequently leading to unsatisfactory results, would more than pav for the expert handling of matters in dispute by the central authority.

There can be no difference of opinion upon the fact that the central authority in this matter should be the Local Government Board; and in the legislation which it is sought to promote certain powers in the above-mentioned direction would be given to that Board, and, in addition, measures are introduced to protect the public health against the pollution of she!l-fish.

Mr. Burns received the deputation in a most sympathetic spirit, and expressed the hope of being able to introduce a Bill, dealing with matters referred to by the deputation, in the spring of next year.

\section{SIR JAMES HECTOR, F.R.S.}

$\mathrm{DEATH}$ has removed the last of the four distinguished geologists, F. von Hochstetter, Sir Julius von Haast, F. W. Hutton and Sir James Hector, who together laid the main foundations of the geology of the Dominion of New Zealand.

Sir James Hector was born in Edinburgh on March I6. 1834 , and was the son of Alexander. Hector, a Writer to the Signet. He was educated at the Edinburgh Academy and University, where he matriculated in 1852 , took his degree of M.D. in 1856 , and served as assistant to Edward Forbes and to Sir James Simpson. His knowledge of natural history and medicine, and the influence of Murchison, gained him the post of surgeon and naturalist to Captain Nก. 1985 . VOL. 77$]$
Palisser's expedition to the Rocky Mountains of British North America. The expedition was in the field from 1857 to 1860 , and its best known result was the discovery of the pass by which the Canadian Pacific Railway now crosses from the Great Plains of Canada to the Pacific coast. At the close of the expedition Hector visited the gold-fields of Californa and northern Mexico, and he reported upon the coal mines of Vancouver Island. On his return to Scotland he wrote a series of papers on the botany, ethnography and physical geography of the Canadian Rocky Mountains; and a paper, of modest length, "On the Geology of the Country between Lake Superior and the Pacific Ocean (between $48^{\circ}$ and $56^{\circ}$ N. lat.). ..."

In the year of his return from America he was appointed geologist to the Government of Otago, and there began the main work of his life. He made extensive and arduous journeys through the province of Otago, which still contains the least known and most difficult country in New Zealand. Some of his results were given in 1863 in a New Zealand Parliamentary Paper on "An Expedition to the North-west Coast of Otago," in which he described the discovery of the pass from Martin's Bay to Lake Wakatipu. His success in Otago soon gained Hector promotion from a provincial to a federal appointment. He was made one of the Commissioners for the New Zealand exhibition at Dunedin in $186_{5}$, in preparation for which he made a tour through the colony to report on its economic resources; and in the same year he was appointed director of the Geological Survey of New Zealand and of the New Zealand Coloniaj Museum at Wellington. There, or in his cottage on the Hutt, a few miles away, he lived for more than forty years. During the first half of this time he issued a long series of important contributions to the natural science of New Zealand; their range was wide, for he was director of the zoological museum. the botanical gardens, the meteorological observatory, and the colonial laboratory, as well as of the Geological Survey. He was also for many years Chancellor of the New Zealand University. He nevertheless found time for extensive original researches. He wrote papers on glacial geology, the origin of the rock basins and the volcanic history of New Zealand; his zoological researches were mainly on the Cetacea, seals, and fish, and he wrote on many groups of New Zealand fossils, notably the moas, and oin the discovery of the oldest known penguin, Palæeudyptes. He superintended and edited those valuable series of annual reports issued by the Colonial Museum and by the Geological Survey, beginning in I867, which are the great storehouse of information on New Zealand geology. In 1868 he married the eldest daughter of the late Sir David Monro, who was then Speaker of the New Zealand Parliament. In 1873 he issued a sketch-map of New Zealand geology, of which the edition issued in 1886 , with his "Outlines of New Zealand Geology," is still the best available. In 1879 he compiled an official "Handbook of New Zealand," a work of reference of permanent value, of which a fourth edition was issued in 1886 . In that year he also wrote his wellknown report on the eruption of Tarawera; he maintained that it was not a normal volcanic, but a hydrothermal eruption, due to a vast explosion of the superheated steam with which the ground around Lake Rotomahana was saturated. This view has not been confirmed for the eruption of Tarawera as a whole, but it is probably correct for the particular explosion which blew up Lake Rotomahana and its famous pink and white terraces.

Hector's work had meanwhile gained world-wide recognition. He had been elected a Fellow of the 
Royal Society in 1866 ; he received the Order of the Golden Cross from the Emperor of Germany in 1874, the decoration of C.M.G. in 1875 , and promotion to K.C.M.G. in 1887 . He was awarded the Lyell medal of the Geological Society in 1875 , and a founder's medal from the Royal Geographical Society in I89I. In the same year Hector was elected the third president of the Australasian Association for the Advancement of Science, and delivered his address on the history of scientific work in New Zealand. But after this period his work became less important He continued to write short papers; the last which we remember is that on the distribution of the moa in New Zealand, in rgor. But he no longer showed his old energy or success, and the staff of the Geological Survey was transferred to the Mines Department. Hector retained his nominal position as director of the Geological Survey until 1903, but for many years he had no control over the Geological Survey work that was being done in New Zealand. He remained director of the Wellington Museum, the condition of which was often made the subject of severe reproach. Hutton publicly complained in 1899 that the plates that had been prepared years before for the monograph of the fossil Cainozoic mollusca and echinoids of New Zealand were never published, and that the valuable collections of fossils that had been made during the geological survey of the colony were "useless as they now exist in the museum of Wellington." In r903 Hector resigned his appointments; he had for several years previously exercised little influence on scientific work in New Zealand, but the high value and wide range of his own scientific work, and the inspiring example of the energy and administrative capacity, which for so many years he devoted to the service of his adopted land, will secure him one of the foremost places in the roll of distinguished New Zealand pioneers.

\section{J. W. G.}

\section{NOTES.}

THE following list of those to whom the Royal Society has this year awarded medals was received a few hours too late for insertion in last week's Nature. The awards of the Royal medals have received the King's gracious approval:-The Copley medal to Prof. A. A. Michelson, of Chicago, For.Mem.R.S., for his investigations in optica; a Royal medal to Dr. E. W. Hobson, F.R.S., for his investigations in mathematics; a Royal medal to Dr. R. H. Traquair, F.R.S., for his discoveries relating to fossil fishes; the Davy medal to Prof. E. W. Morley, of Cleveland, Ohio, for his contributions to physics and chemistry, and especially for his determinations of the relative atomic weights of hydrogen and oxygen; the Buchanan medal to Mr. W. H. Power, C.B., F.R.S., for his services to sanitary science; the Hughes medal to Prof. Ernest H. Griffiths, F.R.S., for his contributions to exact physical measurement; the Sylvester medal to Prof. W. Wirtinger, of Vienna, for his contributions to the general theory of functions.

THE honours announced on the occasion of the King's birthday on Saturday last are chiefly of political interest. Prof. T. Clifford Allbutt, F.R.S., has been appointed a Knight Commander of the Order of the Bath, but he is the only Fellow of the Royal Society we have been able to find in the list. The new knights include Dr. W. H. Allchin, Dr. W. J. Thompson, and Mr. Charles Whitehead, who is associated with scientific agriculture. Dr. A. Theiler, Government veterinary bacteriologist, Transvaal, has been appointed a Companion of the Order of St. Michael and St. George.

NO. I 985 . VOL. 77]
FURTHER particulars have reached us relating to the scientific expedition that will this month visit the Auckland Islands and the Campbell Islands, primarily to extend the magnetic survey of New Zealand to their sub-Antarctic outliers, but also to make zoological, geological, and botanical observations and collections. The expedition, as announced in NatuRE of October 24 (vol. 1xxvi., p. 644), has been arranged by the Philosophical Institute of Canterbury. The Government S.S. Hinewoa will take the expedition on the occasion of her annual trip to visit the depôts placed on the islands for shipwrecked mariners. Of the two dozen members, about half will be left on the Auckland Islands and the rest on the Campbell Islands, to be picked up on the return of the steamer. Among the zoologists will be Profs. Benham and Chilton and Mr. E. Waite; botany is represented by Dr. L. Cockayne and others, geology by Dr. P. Marshall and others, while the magnetic observers will be headed by Dr. Coleridge Farr, who has been engaged for the last few years in carrying out the magnetic survey of New Zealand.

A SMaLl expedition will proceed from New Zealand in December to the Kermadec Islands. Five young enthusiastic men have arranged to spend twelve months on these uninhabited islands, collecting, observing, and photographing. The results of the expedition will, it is hoped, be worked out by naturalists in New Zealand.

A Christmas course of illustrated lectures, adapted to a juvenile auditory, will be delivered at the Royal Institution by Sir David Gill, K.C.B., F.R.S., on "Astronomy Old and New." The dates of the lectures are December 28 (Saturday), 3I ; January 2, 4, 7, and 9, 1908 .

THE administration building of the Mount Weather Meteorological Observatory of the Weather Bureau was, Science reports, destroyed by fire on October 23. The loss is said to be $5000 l$, including some valuable instruments.

THE Times of November 7 reports that Sir Alfred Jones, president of the Liverpool School of Tropical Medicine, has received a communication from Dr. Kinghorn from Serenje, Zambezi. Dr. Kinghorn records the finding of tsetse-flies, and states that the general opinion throughout the country is that they are rapidly extending. Otherwise the country is singularly free from insect pests. So far, sleeping sickness has not appeared in the district.

A PAPER on disease prevention in the Territorial Army, with a proposed scheme for placing medical officers of health in relation to it, was read on November 8 by Sir Alfred Keogh, Director-General of Army Medical Staff, before the Society of Medical Officers of Health. He explained why an organised military department of sanitation must be called into existence. If in the Territorial Force the work involved is not done in time of war by those who constantly deal with kindred problems in time of peace, it cannot be efficiently done at all. He proposed to ask the medical officers of health of the country to combine in a voluntary organisation, having for its object the preservation of the health of the men who may one day be required to defend the country; to enrol themselves in the Medical Corps of the Territorial Force; to undertake voluntarily the duty of considering the problems to be solved during active operations within their own home area; to be ready to place their knowledge at the disposal of the authorities commanding their divisions of the Territorial Forces. The sanitary department of the Medical Corps would further consist of non-commissioned officers and men detailed to join battalions for the technical duties of water sterilisation, for disinfection, \&c. 